Bangladesh Journal of Bioethics 2010;1(3);52-57

\title{
AN OVERALL VIEW OF BIO ETHICS PRACTICES IN OUR DAY TO DAY LIFE AND IT'S REMEDIES
}

\author{
Z. U. Ahmed \\ Director , Makan Group, Dhaka .Email: payesz@yahoo.com
}

\begin{abstract}
Historically, ethics has been considered the province of religion i.e moral theology and large, still remains so. In most cases religion provides an important answer to the question, why one should act ethically. The ancient Greeks were the first to examine ethics philosophically and thus independently to religion. The major proponents of it were Socrates, Plato and Aristotle in the $5^{\text {th }} \& 4^{\text {th }}$ centuries B.C. Now a days we can see lack of ethics everywhere of our life. This article try to find out -where \& what are the ethics we are lacking behind in our day to days life and it's probable remidies. Morality should be practiced and should start from the -"DINNING TABLE". Beside this Government should pass down policies, which will facilitate this practice to get good citizens. The main thrust of modern ethics or moral philosophy is to attempt to lay the foundations of ethical conduct, which should be bear in mind with good faith.
\end{abstract}

Introduction: Ethics is related to morality . In the past the subject of ethics was known as -"Moral philosophy"-while knowledge of the physical world was referred to as-"Natural philosophy". Historically, ethics has been considered the province of religion i.e moral theology and large, still remains so. In most cases religion provides an important answer to the question,- why one should act ethically. The ancient Greeks were the first to examine ethics philosophically and thus independently to religion. The major proponents of it were Socrates, Plato and Aristotle in the $5^{\text {th }} \& 4^{\text {th }}$ centuries B.C . Now a days we can see lack of ethics everywhere of our life. It include our personal life, family life, social life and official life. This article tries to find out - Where $\&$ what are the ethics we are lacking behind in our day to days life and it`s probable remidies .

Historical Back Ground of implementing ethics: The belief that rational thinking and knowledge can lead to ethical behavior was very appealing. Plato believed that Philosopher kings can be trusted with unchecked power because their education will have given them knowledge of the forms, inparticular the form of the good, being eternal, extra-mental realities.

Socrates, unlike religion did not provide instruction how people should conduct their lives. Instead, he examined human conduct with the aim of leading a virtuous life. He believed in 
goodness but did not suggest how to achieve it ?. His continuous questioning of things got him in trouble by being accused of corrupting the youth of Athens and he was put to death for it . We are at this moment not in that barbarian`s era but at Mordarn era where openion of personal expression is honoured and logically discused with good faith.

Ethical Principles: The following principles (Thiroux, 1986) are guidelines for regulating ethical behavior.

- Value of Life - Human life has inviolable sanctity. “. . . it is always wrong to act in a way which directly intends to harm or to kill an innocent human person" (Goodwin, 1985, p. 7).

- Goodness or Rightness - Ethical decisions should involve the principle of the greatest good for the greatest number. Doing good, in addition to refraining from doing evil, is required so that the consequences are good for the individual and for society.

- Justice or Fairness - This principle relates to equality of treatment and fair distribution of benefits and burdens among members of society.

- Truth-telling or Honesty - Although ethical action should be based on the truth, this principle is complicated by issues related to who has a right to the truth and whether or not it is appropriate to withhold it. When do you know you have all of the facts and can determine what is true? Confidentiality (contact-keeping), related to honesty and individual freedom, poses its own set of complications: What do you do when human welfare conflicts with confidentiality? When do you break a promise?

- Individual Freedom - Ethical decisions should consider the principle of selfdetermination. ". . . treat human beings as ends in themselves, never as means only" (Kant in Goodwin, 1985, p.7). Related to this standard are the following complexities: Whose right is uppermost when one person's autonomy impinges on another? Who should speak for those who cannot speak for themselves?

\section{Ethical Reasoning Steps*}

- Clarify the facts.

- Identify the moral dilemma. What is the ethical question?

- Identify and interpret the relevant ethical principles: value of life, goodness, justice, truth-telling, individual freedom.

- Resolve the conflicts among principles. If more than one principle is involved, which one has precedence?

- State the moral decision.

- Formulate a course of action-action steps: what and how, who, when.

* Adapted from the theory of Thiroux (1985). 
Bangladesh Journal of Bioethics 2010;1(3);52-57

Sectors where ethical improvement is immediately needed:

- Personal life

- Family life

- Social life

- Official life

- National life

- International life

\section{Personal Life}

“Today's Personality holder is tomorrow's Person's leader." So it has got utmost importance to get a well groomed personal among the citizens of a country .This well groomed personality will provide a good person who will lead a good personal life along with other.

\section{Family life}

These well groomed persons together will make a happy family life.

\section{Social life}

These well reputed family members together will form a civilized society-where ethics will be highlighted in its right spirit.

\section{Official life}

At the same time these well reputed Family member will be the part of the office. As such they will be more disciplined, efficient and capable enough to achieve the organizational goal as well as the country goal.

\section{National life}

Once the personal, family, social and official life is disciplined and organized - The national life will be more prosperous, which will lead the country to the International arena with good reputation.

\section{International life}

Once all the nations are good, disciplined and have honor towards ethics in every aspect, then good faith $\&$ relation will be developed \& maintained properly. As a result less war, less unrest will prevail in the world- which is our goal. 
Bangladesh Journal of Bioethics 2010;1(3);52-57

So, we can say grooming up of a kid in the right direction with ethics in every family is utmost important, which will ultimately lead a happy world. There could be -"Two way traffic" (Figure 1):

- (1) One way (Down ward) is Government of that individual country by making policies regarding ethics in the parliament.

- (2) Another way (Upward) is "The family dinning table"- where family members will introduce the kid with quality ethics. Here family member's need to give quality time to their kids and can provide knowledge on.

$>$ Religious faith ( Good for person \& society )

$>$ Other sensible faith (good for person \& society. May be an alternative of religious faith.)

$>$ Righteous duties towards all.

$>$ Others

(These teachings may be changed with the passage of time basing on the ground requirement to do good to others. For this a committee may be formed to introduce ethical handbook like UN-where all ethical subject matter will be written down with guide lines as per the ground requirement).

An Ethical Social example: It is common to refer to the desire for material wealth, mostly expressed in terms of money, as "greed". Webster's dictionary defines greed as "acquisitive desire beyond reason". On the other hand, the pursuit of success in the scientific and engineering professions is referred to as "ambition". Webster's dictionary defines ambition as "eager or inordinate desire for preferment, honor, superiority, power, or attainment". The connotation of these terms is so different that sometimes we tend to refer to an honest businessman as "greedy", and to a dishonest scientist or engineer as "over ambitious". Yet, the consequences of an unethical behavior of an "over ambitious" scientist or engineer can often be more harmful then the unethical actions of a "greedy" businessman. In the scandal surrounding the company Enron, no one died or suffered physical injury. On the other hand, the developer of a drug or medical device that results in a faulty product can cause innumerable damage to life and health of many. Of course, in the latter case, the marketing of the product also involves a profit consideration that is often vested with the same individuals, as it has been so widely demonstrated in the recent high tech euphoria. 
Both the ways should work together - "Upward \& Downward". This is more opined below:

(2) Upward-_Family teaching regarding ethics (Dinning table)

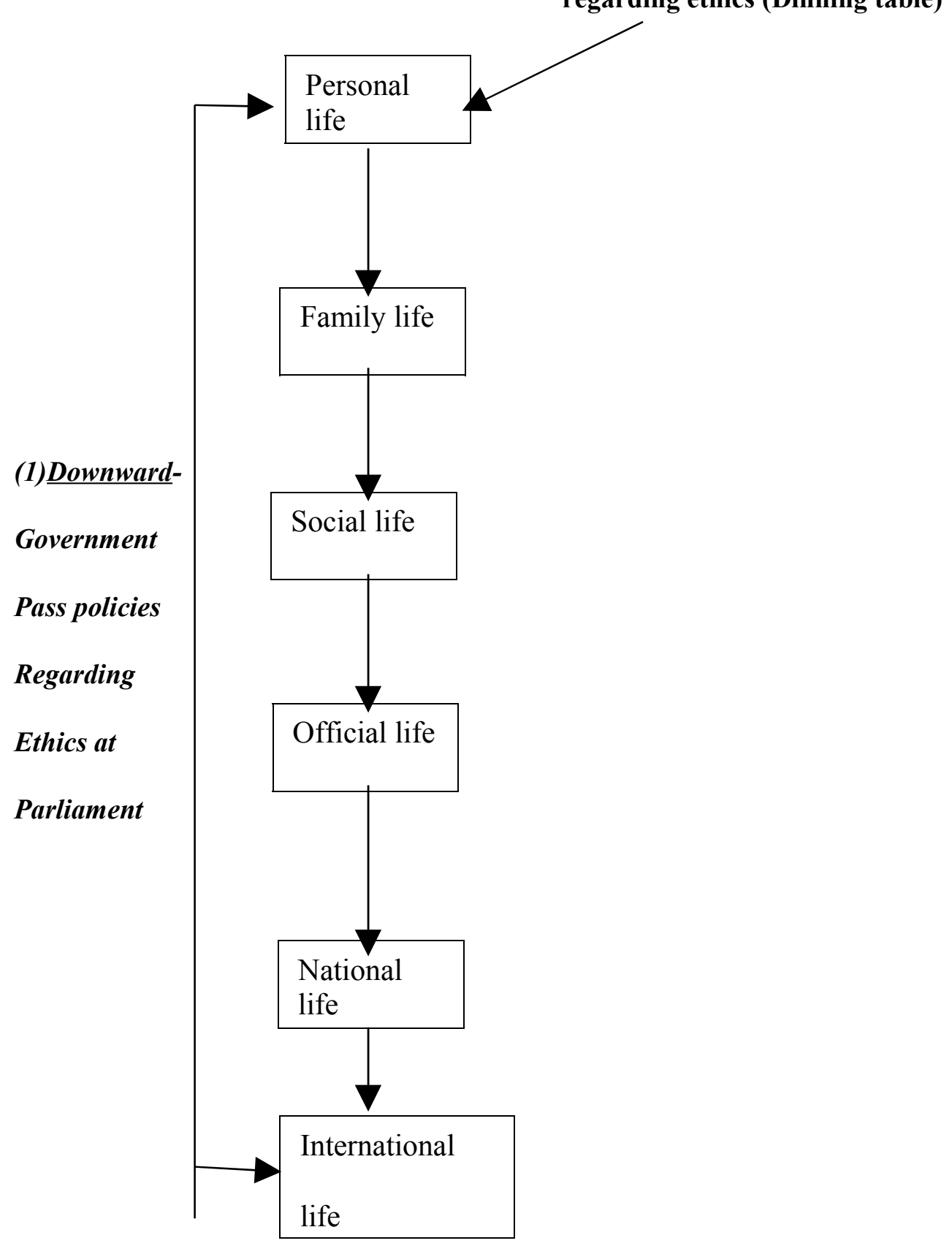

Figure 1: Two- way ethical theory for implementation in our day to day life. 
Conclusion: The subject of ethics was of interest to human kind since before recorded history. Historically, ethics has been considered the province of religion, i.e., moral theology, and, by and large, still remains so. In most cases religion provides an important answer to the question why one should act ethically.

Bioethics is a subset of the larger subject of ethics that is concerned with biological themes. Ethics is related to morality. This morality should be practiced and should start from the -"DINNING TABLE". Beside this Government should pass down policies, which will facilitate these practices to get good citizens. The main thrust of modern ethics or moral philosophy is to attempt to lay the foundations of ethical conduct, which should be bear in mind with good faith.

\section{Bibliography:}

1. www.tutor2u.com

2. Www.wikipedia.com

3. www.cbhd.org

4. Darryl R.J.Macer Moral Games for teaching Bioethics. UNESCO Chair, 2008. Haifa, Israel.

5. Arif Hossain \& Shamima P Lasker. Importance of bioethics and Bangladesh Prospective. Asian Bioethics Review 2009;1(2):165-167.

6. Goodwin. 1985, p.

7. www.bioethics.com 